\title{
SISTEM INFORMASI MANAJEMEN BERBASIS WEB PADA SEKOLAH ISLAM
}

\author{
AL-FAUZIEN \\ Widya Khafa nofa \\ Fakultas Ilmu Komputer, Universitas Gunadarma \\ w_khafa@staff.gunadarma.ac.id
}

\begin{abstract}
Abstrak
Sekolah islam Al-fauzien adalah salah satu penyelenggara pendidikan formal berjenjang dasar yang setara dengan sekolah dasar. dalam menjalankan pendidikan sekolah islam ini menggunakan media kertas, seperti pada dokumen-dokumen, dan berkas surat menyurat sampai pencatatan transaksinya. Seiring berjalannya waktu manajemen yang pada awalnya menggunakan media kertas dan buku mulai terlihat beberapa ketidakberesan. Ketidakberesan tersebut kalau dibiarkan akan mengganggu aktifitas dan akan menghambat tercapainya tujuan.

Teknologi informasi yang semakin berkembang banyak digunakan sebagai alternative solusi untuk menyelesaikan beberapa masalahdikarenakan kecepatan proses yang tinggi dan dengan tingkat kesalahan proses yang kecil. Kehadiran teknologi informasi di dalam dunia pendidikan terutama sekolahislam Al-fauzien akan sangat menujang efisiensi kinerja sehingga mendapatkan dampak yang positif di dalam suatu aktifitas sekolah. Teknologi informasi adalah sarana yang digunakan untuk membantu mencapai hasil kerja yang optimal dan dapat menunjang informasi yang cepat dan akurat.
\end{abstract}

\begin{abstract}
$\mathrm{Al}$ - fauzien Islamic School are one of elementary school . Management at Islamic school still using book and paper as in the documents, and files correspondence to recording the transaction. And in time, management initially using paper media and books began to look a few irregularities if the irregularities still at this islamic school, it will hinder some goals. As the web gets bigger, this approach actually improves for alternative solution to resolve some problems due to the high processing speed with low error. The presences of information technology in education, especially in Al-fauzien Islamic school will greatly support its efficiency performance thus have a positive impact in school activities. Information technology is a tool for supporting and produces optimal results quickly and accurately
\end{abstract}

Keywords: Sistem informasi manajemen, Website, UML 


\section{PENDAHULUAN}

Sekolah Dasar adalah salah satu pendidikan formal sebagai dasar mula suatu pendidikan.Meskipun dengan jenjang pendidikan dasar, tidak bisa dipungkiri bahwa sekolah dasar memerlukan adanya manajemen, Manajemen dapat berupa pengelolaan pegawai, guru-guru, nilai, raport, jadwal sekolah, sampai keuangan, dan inventori. Dengan adanya manajemen yang baik kegiatan dalam sekolah dapat berjalan dengan baik tanpa adanya masalah atau hambatan yang berarti

Al-Fauzien adalah sekolah islam swasta yang menyelenggarakan pendidikan formal dasar atau setara dengan sekolah dasar. Manajemen yang berada di sekolah islam Al-Fauzuen meliputi manajemen perpustakaan, keuangan, kasir, Guru walikelas, Guru spesialis,siswa, nilai, inventaris, dan pegawai. Dalam menjalankan manajemen sekolah masih mengunakan media kertas dan buku, sebagai pencatatan data-data, dan dokumen yang dibutuhkan.

Pada awalnya manajemen pada sekolah islam Al-Fauzien berjalan dengan baik meskipun menggunakan media kertas. namun seiring berjalannya waktu mulai dirasakan adanya kendala dalam manajemen sekolah tersebut. Kendala yang dimaksud seperti lamanya pencarian data, pembuatan laporan keuangan yang lebih sering terlambat, beban kerja guru-guru lebih tinggi saat akhir semester yaitu dalam membuat raport siswa.

Berdasarkan latarbelakang diatas, penulis akan meneliti untuk merancang dan membangun sebuah sistem informasi manajemen studi kasus di sekolah islamAL-Fauzien. Dengan adanya sistem informasi ini diharapkan akan mengatasi masalah.

\section{Konsep Dasar Sistem}

1. Menurut (Stoa, 2008:80) "Pengertian dari sistem merupakan gabungan dari keseluruhan langit dan bumi yang saling bekerja sama yang membentuk suatu keseluruhan dan apabila salah satu unsur tersebut hilang atau tidak berfungsi, maka gabungan keseluruhan tersebut tidak dapat lagi kita sebut suatu sistem".

2. Menurut (Kerz, 2008:175)“Sistem yaitu gabungan dari sekelompok komponen baik itu manusia atau bukan manusia (non-human) yang saling mendukung satu sama lain serta diatur menjadi sebuah kesatuan yang utuh untuk mencapai suatu tujuan, sasaran bersama atau hasil akhir".

\section{Sistem Informasi Manajemen}

Sistem Informasi Manajemen (SIM) menurut O'Brien (2002) dikatakan bahwa SIM adalah suatu sistem terpadu yang menyediakan informasi untuk mendukung kegiatan operasional, manajemen dan fungsi pengambilan keputusan dari suatu organisasi.

Tujuan SIM, yaitu:

- Menyediakan informasi yang dipergunakan di dalam perhitungan harga pokok jasa, produk, dan tujuan lain yang diinginkan manajemen.

- Menyediakan informasi yang dipergunakan dalam perencanaan, pengendalian, pengevaluasian, dan perbaikan berkelanjutan.

- Menyediakan informasi untuk pengambilan keputusan.

Secara sederhana dapat dikatakan bahwa sebuah sistem informasi melakukan pemrosesan data dan kemudian mengubahnya menjadi informasi. Menurut O'brien (2010) SIM merupakan kombinasi yang teratur antara people, hardware, software, communication network dan data resources (kelima unsur 
ini disebut komponen sistem informasi) yang mengumpulkan, merubah dan menyebarkan informasi dalam organisasi seperti pada Gambar 1.

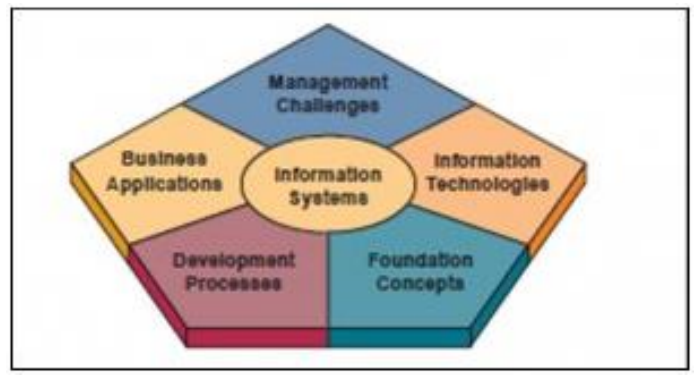

Gambar 1. Komponen Sistem Informasi

Terdapat 3 peran utama sistem informasi dalam bisnis yaitu :

\section{- Mendukung proses bisnis dan operasional \\ - $\quad$ Mendukung pengambilan keputusan \\ - Mendukung strategi untuk keunggulan kompetitif}

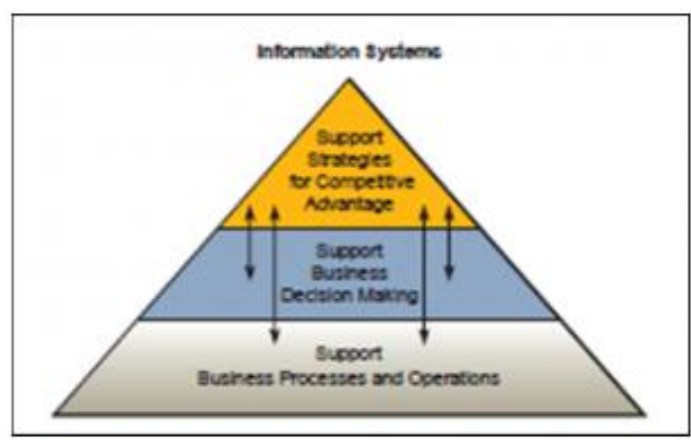

Gambar 2. Tiga Peran Utama Sistem Informasi

\section{Analisis Sistem}

Analisis sistem dapat didefinisikan sebagai penguraian dari suatu system informasi yang utuh ke dalam bagian bagian komponennya dengan maksud untuk menidentifikasikan dan mengevaluasi permasalahan permasalahan, kesempatan - kesempatan, hambatan - hambatan yang terjadi dan kebutuhan - kebutuhan yang diharapkan sehingga dapat diusulkan perbaikan perbaikannya (Jogiyanto, 1999:129).

Tujuan utamanya adalah untuk memahami sistem dan masalah yang ada, untuk menguraikan kebutuhan informasi dan untuk menetapkan prioritas pekerjaan system selanjutnya.

Terdapat empat tahap atau langkah umum dalam analisis sistem :

1. Analisis sistem berjalan.

2. Mengidentifikasi kebutuhan informasi pemakai.

3. Mengidentifikasi kebutuhan sistem yang perlu untuk memenuhi kebutuhan informasi pemakai.

4. Penyajian laporan analisis sistem.

Dalam memahami kerja dari sistem yang ada dari beberapa tugas yang perlu dilakukan, sebagai berikut :
a. Menentukan Jenis Penelitian
b. Merencanakan Jadwal Penelitian
c. Membuat Penugasan Penelitian
d. Membuat Agenda Wawancara
e. Mengumpulkan Hasil Penelitian

\section{UML (Unified Modeling Language)}

Unified Modelling Language adalah suatu bahasa standar untuk menulis cetak biru software. UML digunakan untuk visualisasi, spesifikasi, konstruksi, dan mendokumentasikan artifacts (sepotong informasi yang digunakan atau dihasilkan dalam suatu proses rekayasa software. Artifacts dapat berupa model, deskripsi, atau software). Pada bagian ini akan dibahas mengenai diagram dalam UML dan bagaimana pemanfaatannya.

UML menggunakan beberapa diagram yang memiliki fungsi tersendiri. Diagram tersebut antara lain adalah :Use_Case Diagram, Class Diagram, Behaviour Diagram, Activity Diagram, Statechart Diagram, Interaction 
Diagram, Sequence Diagram, Collaboration Diagram, Implementation Diagram, Component Diagram dan Deployment Diagram

Dari diagram yang dimiliki oleh UML, tidak seluruhnya wajib digunakan. Diagram yang digunakan dapat disesuaikan dengan kebutuhan.

\section{METODE PENELITIAN}

Data yang diteliti adalah data yang berhubungan dengan kegiatan sehar0 hari manajemen.Penelitian ini memberi gambaran kepada pembaca dan mengungkapkan suatu masalah, keadaan, peristiwa sebagaimana adanya atau mengungkapkan fakta secara detail, kemudian mengusulkan sebuah sistem informasi manajemen yang mampu mengatasi masalah.

\section{HASIL DAN PEMBAHASAN}

\section{Identifikasi Masalah}

Sekolah Islam Al-fauzien yang bergerak dalam bidang pendidikan dasar.berdasarkan hasil wawancara yang dilakukan kepada beberapa bagian yang memiliki kendala, didapat hsil sebagai berikut:

Tabel 1. Indentifikasi masalah

\begin{tabular}{|c|c|c|c|}
\hline $\mathrm{NO}$ & Bagian & Kendala & Penyebab \\
\hline 1. & Guru & 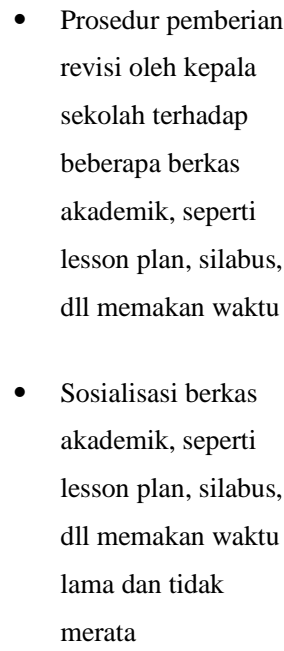 & $\begin{array}{l}\text { - Waktu } \\
\text { kehadiran } \\
\text { kepala } \\
\text { sekolah dan } \\
\text { guru ybs } \\
\text { seringkali } \\
\text { tidak } \\
\text { - } \text { Kehadiran } \\
\text { guru yang } \\
\text { berbeda-beda } \\
\text { sampai } \\
\text { terlupanya } \\
\text { menginfokan }\end{array}$ \\
\hline
\end{tabular}

\begin{tabular}{|c|c|c|c|}
\hline & & 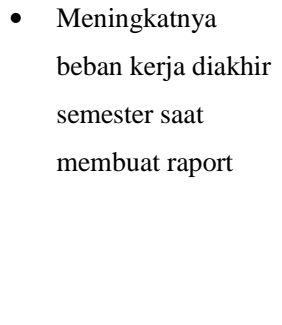 & $\begin{array}{l}\text { Banyaknya } \\
\text { murid dan } \\
\text { adanya } \\
\text { formula nilai } \\
\text { raport yang } \\
\text { tidak } \\
\text { sederhana }\end{array}$ \\
\hline 2 & Hrd & $\begin{array}{l}\text { Pencarian data } \\
\text { siswa memerlukan } \\
\text { waktu yang lama }\end{array}$ & $\begin{array}{l}\text { - Hrd harus } \\
\text { melakukan } \\
\text { pencarian } \\
\text { setiap untuk } \\
\text { menemukan } \\
\text { data dimaksud }\end{array}$ \\
\hline 3 & $\begin{array}{l}\text { Kasir } \\
\text { dan } \\
\text { keuang } \\
\text { an }\end{array}$ & $\begin{array}{l}\text { Proses pembayaran } \\
\text { sampai pembuatan } \\
\text { lapoan keuangan } \\
\text { memakan waktu } \\
\text { lama, }\end{array}$ & $\begin{array}{l}\text { Kurangnya } \\
\text { koordinasi } \\
\text { Antara kasir } \\
\text { dan keuangan } \\
\text { seperti } \\
\text { pemberian } \\
\text { kuitansi } \\
\text { pembayaran. }\end{array}$ \\
\hline 4 & $\begin{array}{l}\text { Perpus } \\
\text { takaan }\end{array}$ & $\begin{array}{l}\text { - Pencarian buku dan } \\
\text { data siswa sampai } \\
\text { peminjaman } \\
\text { memakan waktu } \\
\text { lama }\end{array}$ & 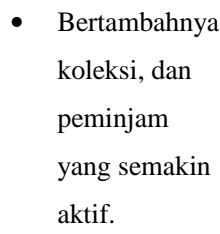 \\
\hline
\end{tabular}

\section{Kebutuhan - Kebutuhan Informasi dan Sistem.}

Dari permasalahan - permasalahan yang telah diidentifikasi sebelumnya, dapat diketahui bahwa permasalahan yang timbul akibat tingkat efisiensi dan efektifitas yang masih kurang dan banyak terjadi kesalahan manusia (human error). Pemrosesan data diperusahaan masih menggunakan cara manual sehingga dibutuhkan waktu yang lama untuk menghasilkan suatu informasi. Adapun kebutuhan sistem informasi adalah sebagai berikut :

1. Dapat melakukan pembayaran dan pembuatan laporan dengan cepat dan lebih baik. 
2. Mengurangi kesalahan yang diakibatkan kurang baiknya administrasi dan birokrasi.

3. pencatatan, pencarian data menjadi lebih cepat dan efektif.

Dengan sistem informasi yang terkomputerisasi, banyak permasalahan di sekolah islam Al-Fauzien yang dapat ditangani, selain itu sistem informasi terkomputerisasi juga dapat menguntungkan sekolah islam AlFauzien dalam melakukan pembayaran yaitu dengan cara sebagai berikut:

1. Sistem informasi yang terkomputerisasi akan menyediakan pelayanan yang lebih baik, dengan mempercepat proses pembayaran dan mengurangi kesalahan - kesalahan yang terjadi.

2. Sistem informasi akan menyediakan informasi - informasi yang dibutuhkan oleh sekolah islam Al-Fauzien untuk mengatasi dalam pembuatan laporan keuangan nantinya.

3. Sistem informasi akan dapat meningkatkan produktifitas kerja pegawai sehingga pelayanan sekolah islam Al-Fauzien tersebut meningkat.

\section{Usulan Sistem}

Sebagai solusi permasalahan sekolah islam Al-fauzien, perlu dibuat system terkomputerisasi yang akan dibuat berbasis web. Berikut adalah model system usulan dengan usecase diagram untuk bidang akademik, dengan actor kepala sekolah, admin akademik, guru spesialis, guru kelas, admin akademik,

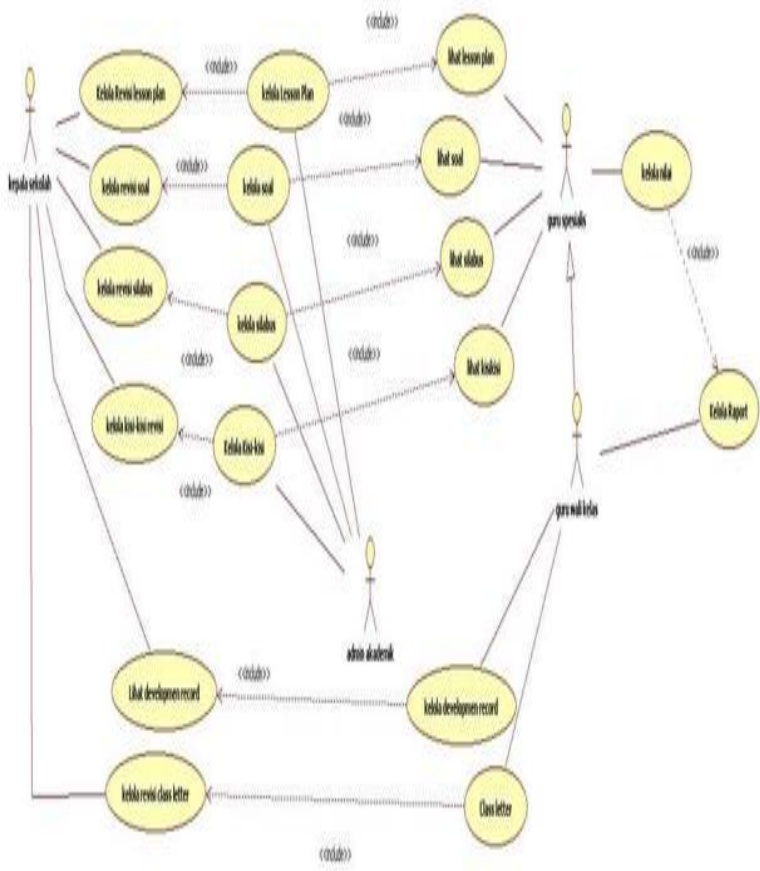

\section{Gambar 7 Diagram Usecase system usulan bidang akademik sekolah.}

Actor kasir dan keuangan harus terintegrasi sehingga kegiatan(pembuatan kuitansi) yang dilakukan kasir dapat diketahui oleh bagian keuangan tanpa harus saling tunggu.
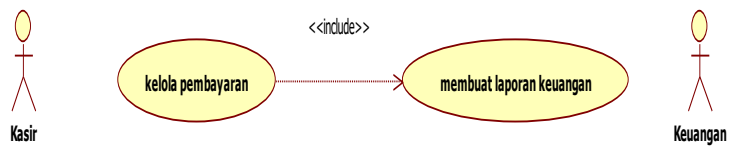

\section{Gambar 8 Diagram usecase untuk Kasir dan keuangan.}

Aktor HRD yang bertugas melakukan pengelolaan data pegawai, guru, dan siswa sangat memerlukan adanya teknologi informasi, untuk mengoptimalkan pencarian data. Berikut diagram usecase untuk HRD: 


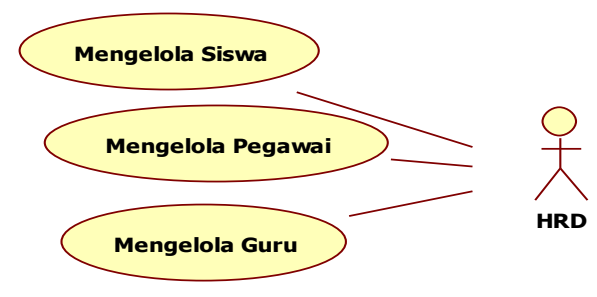

Gambar 9 Diagram usecase untuk HRD

\section{Struktur Navigasi}

Sistem yang akan dibuat adalah berbasisweb, dan untuk memodelkan navigasi atau perpindahan antar halaman website dibutuhkan model struktur navigasi. Jenis navigasi yang terbentuk adalah navigasi campuran, dimana terdapat sifat hirarki dan linier. Dikarakan hirarki seperti pada halaman yang tersusun atas user dan menu, kemudian dikatakan linier karena ada beberapa halaman web yang terurut dan tidak bisa dilewati seperti pada halaman login. Gambar 10 memperlihatkan struktur navigasi website.

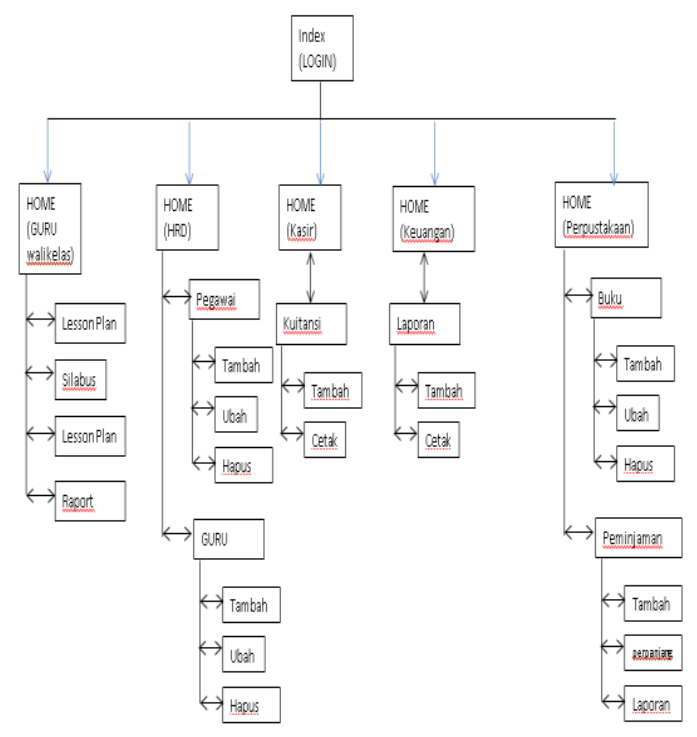

Gambar 10. Struktur Navigasi Website

\section{Desain Program}

Setelah dilakukan permodelan sistem usulan, selanjutnya adalah perancangan desain aplikasi yang sesuai dengan kebutuhan masing-masing aktor. Masing-masing aktor mempunyai akun login yang berbeda - beda. Berikut adalah tampilan login yang merupakan tampilan awal aplikasi;

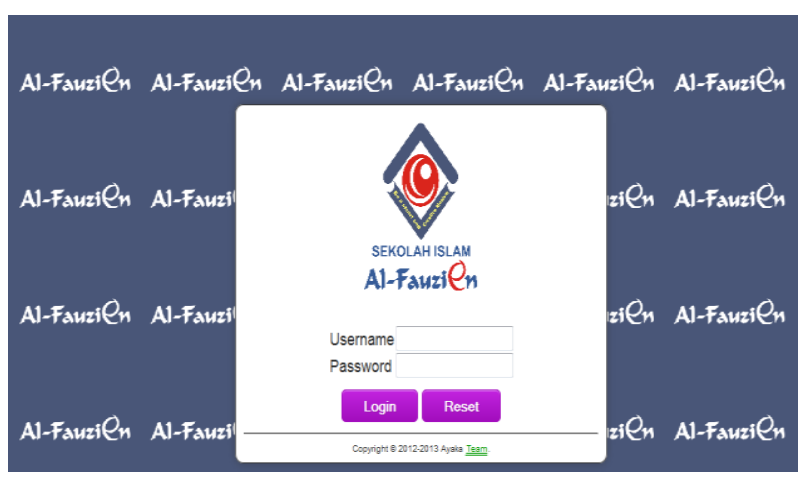

Gambar 11. Desain aplikasi tampilan awal LOGIN

Bidang akademik Berikut tampilan desain web untuk bidang akademik.

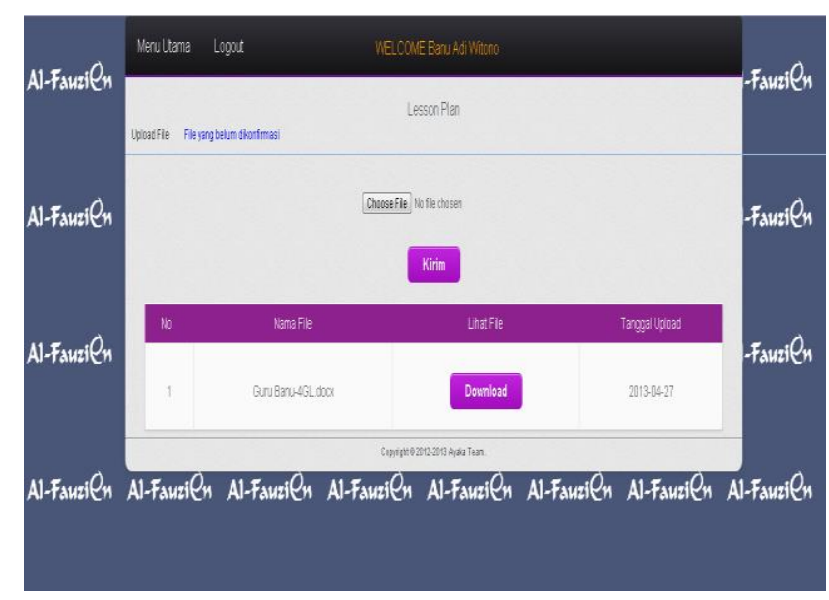

Gambar 12. Desain aplikasi untuk bidang akademik

Bidang keuangan meliputi membuat laporan keuangan yang berasal dari aktifitas kasir, berikut gambar desain tampilan untuk keuangan untuk mengelola akun keuangan. 


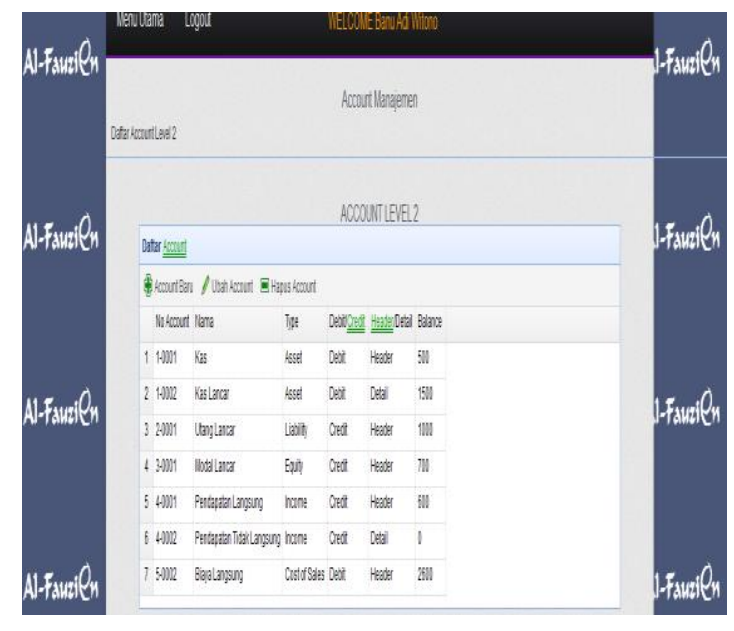

\section{Gambar 13. Desain aplikasi untuk bidang keuangan}

Bidang hrd meliputi pengelolaan data pegawai, data guru, dan siswa. Berikut gambar desai tampilan hrd untuk mengelola data pegawai.

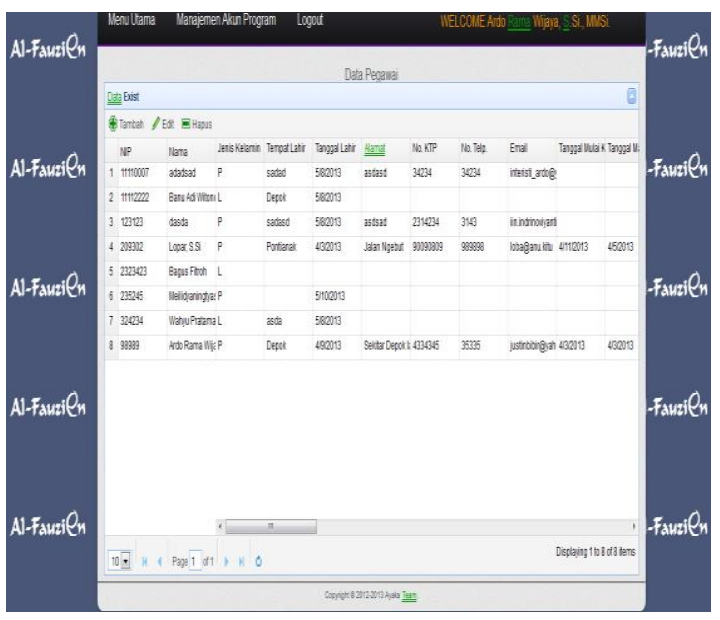

Gambar 14. Desain aplikasi untuk bidang HRD

\section{Kesimpulan}

Selolah islam Al-fauzien yang awalnya menggunakan media kertas dalam menjalankan manajemen sekolah, mempunyai beberapa masalah seperti, dalam birokrasi antar bagian , pembuatan laporan, pencarian data yang memakan waktu sehingga menurunnya kinerja pegawai.

Dengan telah dianalisa dan dibuatnya sistem berbasis web untuk manajemen sekolah islam al-fauzien ini, manajemen sekolah islam al-fauzien telah terkomputerisasi dengan berbasis web sehingga birokrasi antar bagian, pembuatan laporan, sampai pencarian data menjadi lebih efisien sehingga dapat meningkatkan kinerja pegawai.

\section{Saran}

Untuk meningkatkan efektivitas sistem manajemen sekolah al-fauzien ini diharapkan website dapat diakses secara online misalkan pada publikasi nilai, kurikulum, maupun profil sekolah dengan begitu citra yang akan diperoleh akan semakin baik.

Penelitian ini diharapkan dapat dikembangkan atau menjadi bahan referensi bagi para pengembang atau pembuat atau para pengembang sistem manajemen sekolah yang serupa, untuk dapat membangun sebuah sistem manajemen sekolah yang lebih baik dalam hal meningkatkan efktifitas dan kinerja pegawai.

\section{DAFTAR PUSTAKA}

Eriek, (2004) "Aplikasi Web dengan PHP dan Mysql”. Property Of a Ples Ardelindo.

H Rafiza (2006) "Panduan dan Referensi Kamus Fungsi PHP5 Untuk Membangun Database Berbasis $W e b$ ". Elex Media Komputindo.

Haryanto, Steven (2005) "Kumpulan Resep Query Menggunakan Mysql". Dian Rakyat,

Munawar, (2005) "Pemodelan Visual dengan UML”. Graha Ilmu,

Nugroho, Eko, Dr. Ir. M.Si.(2008) Sistem Informasi ManajemenKonsep, Aplikasi dan Perkembangan. Yogyakarta: Andi Offset, 
Sutarman, Muhammad (2010). Analisa dan Desain Sistem Informasi. Kediri: Pustaka Jaya,

Supardi, Yuniar. (2011). Semua Bisa Menjadi Programmer VB6 Hingga VB 2008 Case Study. Jakarta: PT Elex Media Komputindo

Sutanta, E. (2011). Basis data dalam tinjauan konseptual. Yogyakarta : Andi Offset

Umar, A. (2015). Rancang bangun aplikasi rekam medis poliklinik universitas trilogi. Jakarta : Jurnal Informatika Vol. 9, No. 1, Jan 2015 : 1017-1027 